\title{
Extraction of Semantic Intormation from an Ordinary English Dictionary and its Evaluation
}

\author{
Jun-ichi NAKAMURA, Makoto NAGAO \\ Departimsnt of Electrical Engineering, \\ Kyoto University, \\ Yoshidahommahi, Sakyo, Kyoto, 606, JAPAN
}

\begin{abstract}
Anstrar:
The a somatic ertraction of semantic infonation, sspecially stmantic relationships botween words, from un ordinery lighlish dictionary is degcribed. For the extraction,

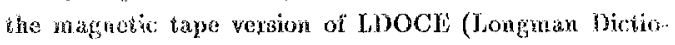
naty of Contemporary Wuglish, 1978 edition) is loaded into a refational database syston. Developed extraction programs analyze a definition sentence in T.DOCN with a potbon watching based algonitho. Since this algoriam is not perfect, the result of the extraction has been conpared with semutic infontation (sementic markess) which the nagnetic tape ression of YDOCL contains. 'l'he resuli of comparison is also discussed for evaluabing the reliability of such ith antomatic extraction.
\end{abstract}

\section{Thentoduction}

A large dictionary database is an important component of a that. ural langaage processing system. We atready know syntactic information which should be and can bestored in a laxge dictionary database for is practical application such as a machine translation system. However, we still need wore research on acmathe information which can be prepared for a large system. As a first step to construct a large scale somantic dictionary (lexical knowledge baso) the authors of this paper have inspected $n$ machine read able ordinary linglish dictionary LDOCF, Mongman Dictionary of Contempozary Gnglish, 1978 edition [Procter 1987].

Extracing semantic ixformation forn an ordinary dictionary is an interesting research topic. One of the aims of antomatic ex. traction is to produce a thesaurns. Nö̈l, for example, proposed the idea of thesaurus production from T,DOCH in [Noël 1982]. Amsler also showed the result of automatic thesaurus production from a techriucal encyclopedia [Amsler 1987]. Boguraev and Alshawi have stadied the utilization of LDOCW for natural language processing re;earches in general [Alshwai 1987, Hognraev 1987].

In this paper, the automatic extraction of somantic relationships between words from 1 DOCH is described. For the ex iraction, the magnetic tape version of roOCE is londed into relational database system. Developed extraction prograns analyze the definition sentence in CnOCW with a pattem matching based algonthn. Since this algorithm is not perfect, the result of the extraction has been compared with semantic infornation (semantic markes) which the magnetic tape version of T,DOCE contains. The result of comparison is also discussed for evaluating the reliability of such an automatic extraction.

\section{HOW Vession of LDOCH}

In general, a dictionary consists of a complex data structure: varions relationships between words; grammatical information; usuge notes, ete. 'Therefore, we need a special datibasc managemert. system to handle dictionary datia. For instance, [Nagao 1980] shows such a system for retrieving a Japanose dictionary. In this paper, however, the authois are mainly interested in the definition and the sample sentence parts of LDOCH, instead of cont plex relations among information in the dictionary.

Fon the sake of efliciency (including the cost of systom dovelopment) of LDOCE tetrieval, we have decided to use a conventional relational database management system (RI)BM). The MDBR which we use is running on the maindrame conputer of Kyoto University Data Processing Center (Fujitsu Mr82, OS/IV

M4 MSP, TACOM AMM/RDB).

for loading the ragnetic version of $\mathrm{LDOCH}$ into this RDBM, we have extracted the following fields from LDOCH:

1. Mead Word (INW); 2. Part-of-Spech (PS); 3. Defi nition Number (DN); 4. Grammar Code (GC); 5 . Bow Code (BC); 6. Definition (DF); and ' 7 . Sample Sen tence (SP).

The Box Code field contains various information such as sematic restrictions, etc, which are explained in section 4.1.

The fields 1 through 5 are almost the sane as the original LOOCE datia. (Several special characters are removed or changed into standard characters for sinplicity of retricval. The syllable division mark (.) is removed. Some of the font control characters are changed into ' $<$ ' and ' $>$.')

'The definitions and the sample sentences are separated into a clause or a sentence. For example, definition 1 of the verb to abandon is:

to leave completely ind for ever; desent

in the original data. This definition is tronsformed into two separate clauses in the RDB version:

1. to leave completely and for ever

2. desert

Since every data in the RDA is represented in a tabular form, we have made three tables for the RDB version of CDOCW (10OCW/RDB, see table 1 regarding their its record format): 
1. Grammar Code and Box Code Table (LDB.D1).

2. Definition 'Table (LOB.D2, see table 2).

3. Sample Sentence Table (LDB.D3).

\section{Extraction of Semantic Information}

One form of semantic infornation useful for natural language processing is a thesaurus (or semantic network), which basically describes semantic relations between words. To automatically produce the thesaurus from LDOCE, two programs have been developed:

1. Key Verb extraction program.

2. Key Noun and Function Noun extraction program.

These programs and the result of extraction are discussed in this section.

\subsection{Key Verb Extraction Program}

Most of the definitions of verbs in LDOCE are described as:

to VleRB ...

Usually VERB in this pattern expresses a 'key concept' of the defined verb. Therefore, we coll this VERB a Key Verb.

For example, the verbs semantically related to the verb to hit have the following definitions:

- strike: to hit

Table 1: Record Format and Size of LDOCE/RDB

D1: Grammar Code and Box Code Table (74,130 records)

\begin{tabular}{|c|c|c|c|c|c|}
\hline $\begin{array}{c}\text { Column } \\
\text { Name }\end{array}$ & $\begin{array}{c}\text { IIW } \\
\text { Ilead } \\
\text { Word }\end{array}$ & $\begin{array}{c}\text { PS } \\
\text { Part of } \\
\text { Speech }\end{array}$ & $\begin{array}{c}\text { DN } \\
\text { Definition } \\
\text { Number }\end{array}$ & $\begin{array}{c}\text { GC } \\
\text { Grammar } \\
\text { Code }\end{array}$ & $\begin{array}{c}\text { BC } \\
\text { Box } \\
\text { Code }\end{array}$ \\
\hline $\begin{array}{c}\text { Attribute } \\
\text { Index }\end{array}$ & $\begin{array}{c}\text { char(20) } \\
\text { IIIIW }\end{array}$ & $\begin{array}{c}\text { char(10) } \\
\text { IIPS }\end{array}$ & $\begin{array}{c}\text { char(10) } \\
\text { IIDN }\end{array}$ & $\begin{array}{c}\text { char(36) } \\
\text { I1GC }\end{array}$ & $\begin{array}{c}\text { char(14) } \\
\text { I1BC }\end{array}$ \\
\hline
\end{tabular}

D2: Definition Table (84,094 records)

\begin{tabular}{|c|c|c|c|c|}
\hline $\begin{array}{c}\text { Column } \\
\text { Name }\end{array}$ & $\begin{array}{c}\text { IIW } \\
\text { Head } \\
\text { Word }\end{array}$ & $\begin{array}{c}\text { PS } \\
\text { Part of } \\
\text { Speech }\end{array}$ & $\begin{array}{c}\text { DN } \\
\text { Definition } \\
\text { Number }\end{array}$ & $\begin{array}{c}\text { DF } \\
\text { DeFinition }\end{array}$ \\
\hline $\begin{array}{c}\text { Attribute } \\
\text { Index }\end{array}$ & $\begin{array}{c}\text { char(20) } \\
\text { I2HW }\end{array}$ & $\begin{array}{c}\text { char(10) } \\
\text { I2PS }\end{array}$ & $\begin{array}{c}\text { char(10) } \\
\text { I2DN }\end{array}$ & varchar(250) \\
\hline
\end{tabular}

D3: Examtple Table $(46,122$ records)

\begin{tabular}{|c|c|c|c|c|}
\hline $\begin{array}{c}\text { Column } \\
\text { Name }\end{array}$ & $\begin{array}{c}\text { IIW } \\
\text { Head } \\
\text { Word }\end{array}$ & $\begin{array}{c}\text { PS } \\
\text { Part of } \\
\text { Speech }\end{array}$ & $\begin{array}{c}\text { DN } \\
\text { Definition } \\
\text { Number }\end{array}$ & $\begin{array}{c}\text { SP } \\
\text { SamPle }\end{array}$ \\
\hline $\begin{array}{c}\text { Attribute } \\
\text { Index }\end{array}$ & $\begin{array}{c}\text { char(20) } \\
\text { I3HW }\end{array}$ & $\begin{array}{c}\text { char(10) } \\
\text { I3PS }\end{array}$ & $\begin{array}{c}\text { char(10) } \\
\text { I3DN }\end{array}$ & varchar(250) \\
\hline
\end{tabular}

Table 2: Definition Table (IDB.D2) of $\mathrm{IDOCD} / \mathrm{RDA}$

\begin{tabular}{|c|c|c|c|}
\hline HW & PS & DN & DF \\
\hline abandon & $\mathbf{v}$ & 1 & to leave completely and for ever \\
\hline abandon & $v$ & 1 & desert \\
\hline abandon & $v$ & 2 & $\begin{array}{l}\text { to leave (a relation or friend) in a thought- } \\
\text { less or cruel way }\end{array}$ \\
\hline abandon & $\checkmark$ & 3 & to give up, esp. without finishing \\
\hline abandon & $\mathbf{v}$ & 4 & $\begin{array}{l}\text { to give (oneself) up completely to a fed- } \\
\text { ing, desire, etc. }\end{array}$ \\
\hline abandon & $\mathbf{n}$ & 0 & $\begin{array}{l}\text { the state when one's feelings and actions } \\
\text { are uncontrolled }\end{array}$ \\
\hline abandon & n & $\mathbf{0}$ & freedom from control \\
\hline abandoned & adj & 0 & $\begin{array}{l}\text { given up to a life that is thoughe bo be } \\
\text { immoral se also ABANDON }(2,4)\end{array}$ \\
\hline
\end{tabular}

- beat: to hit many timies, esp. with a stick

- kick: to hit with the foot

- knee: to hit with the knee

From this pattern of definitions, we can draw figure 1 which shows the semantic hierarchy around to hit: to beat, to tich and to knee are specialized verbs of to hit.

To expand this hierarchy, a program to extract the fey verbs from a definition is developed. Table 3 (LDBV.D2) shows some examples of this extraction. In table 4, the frequency of key verbs is listed. Most frequently used key verb is to make. Note that to make and to cause are used to define causative and transitive verbs respectively.

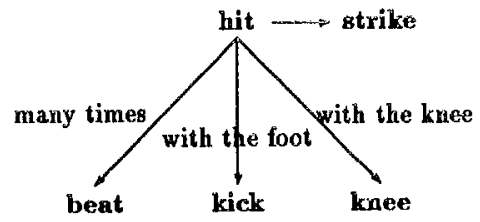

Figure 1: Semantic Hierarchy arround 'hit'

Table 3: Definition and Key Verb Table (LDBV.D2, part)

\begin{tabular}{|c|c|c|c|c|}
\hline HW & KV & PS & DN & DF \\
\hline abase & make & $\mathbf{v}$ & 0 & $\begin{array}{l}\text { to make (someone, esp. oneself) } \\
\text { have less self-respect }\end{array}$ \\
\hline abase & make & $v$ & 0 & make humble \\
\hline abash & cause & $v$ & 0 & $\begin{array}{l}\text { to cause to feel unconfortable or } \\
\text { ashamed in the presence of others }\end{array}$ \\
\hline abate & become & $\mathbf{v}$ & 1 & $\begin{array}{l}\text { (of winds, storms, disease, pain, } \\
\text { etc.) to become less strong }\end{array}$ \\
\hline abate & decrease & v & 1 & decrease \\
\hline abate & make & $\psi$ & 2 & <lit> to make less \\
\hline abate & bring & v & 3 & $\begin{array}{l}\text { <law> to bring to an end (esp. is } \\
\text { the phr. <abate a inisance>) }\end{array}$ \\
\hline
\end{tabular}


'frable t: Hequency of Key Verbs

\begin{tabular}{|c|c|}
\hline $\mathrm{KV}$ & COUNT(KV) \\
\hline melle & 1311 \\
\hline be & 875 \\
\hline cavbe & 641 \\
\hline gives & 505 \\
\hline put & 446 \\
\hline ialice & 358 \\
\hline move. & 383 \\
\hline have & 374 \\
\hline beconite & 336 \\
\hline go & 263 \\
\hline get & 208 \\
\hline$\because$ & \\
\hline
\end{tabular}

Travensing these relations between defined verb and keg verb, a thesturus (network) of verbs has been obtained approximately. Most of the verbs in this thessurus make a treelike structure shown in figure 1. Mowever, several 'loops' are found. A 'loop' expresses a cyclic definition: to welcome is defined by to greet, and to greel is defined by to welcome. In the network, six typical ofyclic definitions are:

- do: co (the verb to do does not have a key verb.)

- chatige: clange, move, cone, become

ig go: go, leave

get: get, receive

- stop: stop, ceuse

- lest: Jet, allow, permit

Note that there are many other cyclic definitions in the network. However, nost of them have a link to another verb; at least one of the verb in a cyclic definitions is defined by another verb.

Since no reader of LDOCE can understand the meaning of these verbs only from the dictionary, these may be a kind of bug of the dictionary. However, these cyclically defined verbs seem to correspond to semantic primitives, which are first introduced to AY works by [Schank 1975]. Semantic primitives may be defined outside of Ving wistic words. Details of the result of extraction are discussed in [Nakamura 1986].

\subsection{Key Noun and Function Noun Extraction Program}

We can apply a similar algorithm to definitions of nouns, although the pattern of definitions of nouns is more complex than that of verbs. Inspecting definitions with $\mathrm{LDOCE} / \mathrm{RDB}$, most of them are classified into two forms:

1. \{determiner $\{\text { adjective }\}^{*}$ Key Nown $\{\text { adjective phrase }\}^{*}$

2. (determiner\} \{adjective\} Function Nowa of Key Noun \{adjective phrase $\}^{4}$

The first one is a sirnple form and many of them express is-a relistions botween sefined noun and is key noss. For example,

abustow: the state when one's feefing and actions are nincontrolled

shows thet ubandon is-a state.

The second form expresses more complex semantic relations between nouns.

abbey: the group of people living in such a building

shows that

nbbey is-a-group-of people.

A function noun, therefore, explicitly expresses the semantic relation between a head word and a key noun.

With terms of a semantic network, defined nouns and key nouns are nodes in a sernantic network, and function nous (when function noun is empty, its function noun is regared as kind) express the name of a link between nodes. 'The following nouns (41 nouns, in total) are considered to be function. nouns, which are manually extracted.

ais-a: kind, type, ...

- part-of: part, side, top, ...

nember-ship: set, member, group, class, family, ...

-action: act, way, action, ...

- state: state, condition, ...

amount: amount, sum, measure, ...

- degree: degree, quality, ...

- form: form, shape, ...

A program to extract key nouns and function nouns from the definitions of nouns is developed. Table 5 shows a part of the key noun and function noun table in the IJOOCE/RI) (LDBN.D2) generated by this program.

As shown in table 6, the key noun of highest frequency is person (2174 times) and for function noun is type (1064 times) except null function noun (pattern 1).

Traversing is-a relation, for example, a thesaurus has been obtained [Nakamura 1987]. Table 7 shows a part of the automatically obtained thesaurus, whose 'root' word is person: actor is a-kind-of person; comedian, extra, ham, and mime are a-kind-of actor; comedienne is a-kind-of comedian.

\section{Comparison between Result of Ex- traction and BOX Code}

The thesaurus produced from LDOCE by the key noun and key verb extraction programs is an approximate one, and, obviously, contains several errors. The key noun of abbreviation 1 , for example, is shorter in table 5 , because the current program ignores ing-formed words. However, it should be making. (Even if we changed the extraction algorithm, still we have a problem that making is not a simple noun, but a genund. We need to define nosn-verb semantic relations.) To evaluate the quality of the produced thesaurus, the noun part of the thesaurus has been compared with the semantic markers in LDOCE. 
Table 5: Definition, Key Noan and function Noun Table (MDAN.D2, prart)

\begin{tabular}{|c|c|c|c|c|}
\hline IIW & $D N$ & $\mathrm{KN}$ & $\mathrm{EN}$ & DF \\
\hline abaidon & 0 & state & & $\begin{array}{l}\text { the state when one's feel- } \\
\text { ings and actions ate uncon- } \\
\text { trolled } \\
\text { freedom from control }\end{array}$ \\
\hline$\cdots$ & & & & \\
\hline abbey & 1 & brilding & & $\begin{array}{l}\text { (esp. formerly) a building in } \\
\text { which Christian men (monk } \\
<\mathrm{s}>\text { ) or women (nun }<\mathrm{s}> \\
\text { ) live shut away from other } \\
\text { people and work as a group } \\
\text { for God. }\end{array}$ \\
\hline abboy & 1 & convent & & monastery $>$ or convent \\
\hline abbey & 2 & people & group & $\begin{array}{l}\text { the group of people living in. } \\
\text { such a building }\end{array}$ \\
\hline abbey & 3 & holuse & & $\begin{array}{l}\text { a large clurch or house that } \\
\text { was once such a building }\end{array}$ \\
\hline & & & & \\
\hline abbreviation & 1 & shorter & act & the act of making shorter \\
\hline abbreviation & 2 & word & form & $\begin{array}{l}\text { a shortened form of a word, } \\
\text { often one used in writing }\end{array}$ \\
\hline
\end{tabular}

Table 6: Trequency of Key Nouns and Function Nouns

\begin{tabular}{l|r||l|r} 
KN & COUNT(KN) & FN & COUNT(FN) \\
\hline person & 2174 & $($ null $)$ & 36583 \\
to & 1660 & ty pe & 1064 \\
something & 668 & act & 838 \\
& 655 & piece & 603 \\
place & 479 & state & 557 \\
mant & 294 & part & 498 \\
matexial & 261 & group & 327 \\
in & 255 & any & 306 \\
people & 253 & quality & 247 \\
plant & 232 & types & 246 \\
subsiance & 226 & set & 208 \\
money & 206 & action & 200 \\
apparatus & 205 & kind & 182 \\
$\ldots$ & & & $\ldots$
\end{tabular}

Table 7: Example of Thesaurus (person)

\begin{tabular}{|c|c|c|}
\hline HW & $\mathrm{DN}$ & $\mathrm{DF}$ \\
\hline \multicolumn{3}{|l|}{ person } \\
\hline$\ldots$ & & \\
\hline accountant & 0 & $\begin{array}{l}\text { a person whose job is to keep and } \\
\text { examine the money accounts of busi } \\
\text { nesses }\end{array}$ \\
\hline $\mathrm{CPA}^{-1}$ & 0 & cartified nublic aceountant \\
\hline ace & 2 & $\begin{array}{l}\text { infml a person of the highest class or } \\
\text { skill in something }\end{array}$ \\
\hline$\ldots$ & & \\
\hline actor & 2 & $\begin{array}{l}\text { a person who takes part in something } \\
\text { that happens }\end{array}$ \\
\hline comedian & 1 & $\begin{array}{l}\text { an actor who a tells jokes or does } \\
\text { amnsing things to make people langl }\end{array}$ \\
\hline comedienne & 0 & a female comedian (1) \\
\hline extra & 2 & $\begin{array}{l}\text { an actor in a cinema film who has } \\
\text { very small part in a crowd scene and } \\
\text { is }\end{array}$ \\
\hline sundry & 0 & extota (4) \\
\hline ham & 3 & $\begin{array}{l}\text { an actor whose acting is unnafu } \\
\text { ral, esp. with improbable movement } \\
\text { and expr }\end{array}$ \\
\hline mirne & 3 & $\begin{array}{l}\text { an actor who performs without using } \\
\text { words }\end{array}$ \\
\hline
\end{tabular}

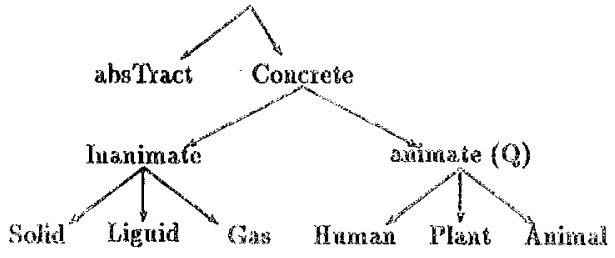

Figure 2: Hierarchy of Sernuntic Murkers in GDOCy

\subsection{Semantic Markers in LDOCH: BOX Oude}

The magnetic version of LDOCL has special field retated to semantic markers, which is called as BOX cote helds, antswagh it does not appear in the printed version of CDOCH. Some of the BOX code field (called BOX1, for instance) express santevatio restrictions for a noun governed by a verb or sin adjective, and is semantic classification of a nown. For exwomple, the semantive re striction for a subject of the verb fo travel is narked as "Wharnand; the nown person is classified as 'Mo." 'This shows thet the wew to travel may govern the nown person in its subject posituras. The LDOCE uses 34 markers for expressing this xestrietion (6able 8 ).

These semantic markers have a hierurchy as shown in sig; ure 2. for example, 'Human', 'Plant', and 'Animal' ares sul. classifications of 'animate (Q).'

In the following part of this section, the coinparison betweat. sernantic markers of LDOCE and the thesauras constructed fiom the definitions of nouns in $\mathrm{CDOCE}$ is discussed frome she wiew

Table 8: Semantic Markers in Box Code of Houns and their Frequency (Part)

\begin{tabular}{|c|c|c|c|}
\hline & type of code & box 1 & $\mathrm{DN}=0, \mathrm{I}$ \\
\hline $\mathrm{A}$ & Animal & 957 & 836 \\
\hline $\mathrm{B}$ & Female Animal & 26 & 15 \\
\hline C & Concrete & 359 & 181 \\
\hline$D$ & Male Animal & 27 & 21 \\
\hline $\mathbf{E}$ & 'S'+' 'L' & 257 & 187 \\
\hline $\mathbf{F}$ & Female Homan & 453 & 314 \\
\hline $\mathbf{G}$ & Gas & 111 & 79 \\
\hline H & Human & 3457 & 2436 \\
\hline 1 & Inanimate & 42 & 26 \\
\hline $\mathrm{y}$ & Movable & 5794 & 3927 \\
\hline K & Male ('D' + 'M') & 2 & 2 \\
\hline $\mathbf{L}$ & Liquid & 631 & 464 \\
\hline $\mathbf{M}$ & Male Human & 875 & 603 \\
\hline $\mathbf{N}$ & Not Movable & 2144 & 1436 \\
\hline 0 & 'A'+ 'H' & 69 & 42 \\
\hline $\mathbf{P}$ & Plant & 758 & 593 \\
\hline$Q$ & Animate & 23 & 14 \\
\hline $\mathbf{R}$ & Female $\left({ }^{\prime} \mathrm{B}^{\prime}+{ }^{6} \mathrm{~F}^{\prime}\right)$ & 4 & 3 \\
\hline $\mathrm{S}$ & Solid & 1291 & 887 \\
\hline $\mathbf{T}$ & Abstract & 36577 & 9668 \\
\hline D & Collective \& $0^{\circ}$ & 789 & 398 \\
\hline V & 'P' + 'A' & 20 & 15 \\
\hline$W$ & ${ }^{\prime \prime} \mathrm{T}$ ' + 'T' & 103 & 61 \\
\hline $\mathrm{X}$ & "T"+ "H" & 197 & 108 \\
\hline $\mathrm{Y}$ & ${ }^{\prime} T^{\prime \prime}+{ }^{\prime} Q '$ & 41 & 18 \\
\hline$z$ & $\begin{array}{l}\text { UNMARKED } \\
\ldots\end{array}$ & 415 & 199 \\
\hline & total & 43560 & 24906 \\
\hline
\end{tabular}




\begin{tabular}{|c|c|c|c|}
\hline mwr & $B 1$ & $\mathrm{KN}$ & $\mathrm{DH}^{4}$ \\
\hline brosed & 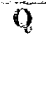 & animat & $\begin{array}{l}\text { 2 lind or class of animal (or plant) } \\
\text { vant. developed under the influence } \\
\text { of inan }\end{array}$ \\
\hline dwet & Q & parasere & $\begin{array}{l}\text { as person, animal, or plant of much } \\
\text { loyst than the usual size }\end{array}$ \\
\hline mastiand & $y$ & plantant & $\begin{array}{l}\text { An minal or glant which is at mix- } \\
\text { vere of breeds }\end{array}$ \\
\hline 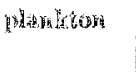 & $y$ & bite & 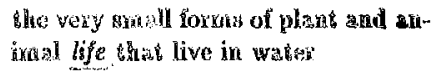 \\
\hline Mate & $x$ & atiental & a ruale person or arival \\
\hline 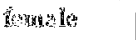 & $a$ & comingal & a fexuale person or animal \\
\hline parent & $\Pi$ & nother & the father or mother of a perion \\
\hline
\end{tabular}

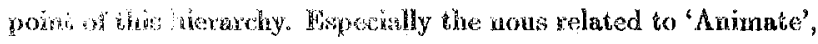

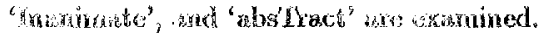

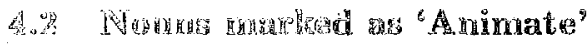

Nowns ratid to the concept animate have a relatively simple structure in the thesanras, as animete is often used as an example of a thesuluts like system. Mamples of the words narked as 'sainaute (O)' and relsted nowns, especinlly marked as 'plant $t$

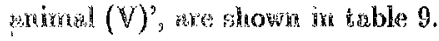

The groduced thesanus contains more than $60 \%$ of the words marted as simphe roncepts, such as 'plant' (table 10), 'knimal', and 'Twman (pessan in definitions)', in correct positions. As shown in table 10, for example, 645 vords are traversed from

Thble 10: Nowns helated to (Kiving) 'rhing and Plant, (living) thing a plant $(P)$

\begin{tabular}{c|rl} 
Bu & $\operatorname{CovNT}(\mathrm{B} 1)$ \\
\hline$A$ & 2 & \\
0 & 2 & \\
$D$ & 370 & $62.4 \%$ \\
0 & 1 & \\
other & 270 & \\
\hline total & 645
\end{tabular}

plews ink throduced thesnurus; 370 words $(62.4 \%)$ of these

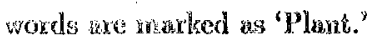

However, the produced thesaurus does not capture disjunctive concey sy seril as 'raninal or plant (V)' correctly. In the definition of crossbred (table 9), the produced thesaurus only uses plant as s key xowir, and ingores atamal. This is a typical problem in the ewareyat produced thescanrus.

fore thet the distinction between 'aximate $(Q)^{3}$ snd 'animal (of plant ( $V$ ' (anmate wibhout human) seems to be dificult for the kexicenghers: breed is nerked as $\mathrm{Q}$; crossbred, however, is

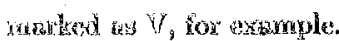

\section{Lo}

Hy 11000 many nouns (about $10 \%$, table 8) we rnarked as "rhsthate, wad they are not classified into more detailed sub

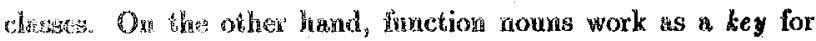

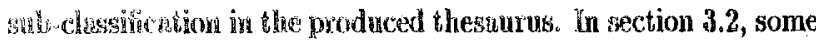

of the function nouns are listed as action, state, amownt and degres. These function nouns classify abstract nouns.

For example, there are 597 nouns whose function noun is act, and 584 nouns (97\%) of them are marked as 'abstract'; there are 398 nouns whose function noun is stale, and 391 nouns (98\%) of them are 'abstract.' 'The distinction between 'state' and 'act,', for instance, is useful for natural language processing in general.

\subsection{Nouns Marked as 'Inanimate'}

Some 'Inanimate' nouns are correctly identified in the produced thesturus (table 11). Fspecially, 39\% of nouns nnder the noun liguid have 'Liquid' markers, and $56 \%$ of nouns under the noun' gas have 'Gas' markers.

However, many 'Inanimate' nouns are defined by substance in LDOCE. Sub-classification of these nom is expressed with a compound word (or an adjective) as shown in table 11: coke is a solid substance; fluorine is a non-metallic substance. Since the currect extraction program does not handle a compound word, the thesaurus cannot express these classification.

\subsection{Other Typical Nouns}

Several typical nouns in the produced thesaurus are also compared with markers of LDOCE. Because the current systern can. not distinguish senses of nouns, nouns which have several different senses causes a problem. A typical example is found in the definitions whose key noun is case. As shown in table 12, atlache case and test case are both defined by case; these expresses com pletely different concept. In 30 nouns whose key noun is case,

Table 11: Examples of Nouns Marked as 'Inanimate'

\begin{tabular}{|c|c|c|c|}
\hline HW & B1 & $\mathrm{KN}$ & $\mathrm{DF}$ \\
\hline hydrogen & $\mathbf{G}$ & gas & $\begin{array}{l}\text { a gus that is a simple substance } \\
\text { (ELEMEN } \text { ), without colour or } \\
\text { smell, that is lighter than air and } \\
\text { that burns very easily }\end{array}$ \\
\hline water & L & liquid & $\begin{array}{l}\text { the most common liquid, without } \\
\text { colour, taste, or smell, which falls } \\
\text { from the sky as rain, forms rivers, } \\
\text { lakes, and seas, and is drunk by peo- } \\
\text { ple and animals }\end{array}$ \\
\hline coke & $\mathbf{S}$ & substance & $\begin{array}{l}\text { the solid substance that remains af- } \\
\text { ter gas has been removed from coal } \\
\text { by heating }\end{array}$ \\
\hline fluorine & $\mathbf{G}$ & substance & $\begin{array}{l}\text { a non-metallic substance, usw. in } \\
\text { the form of a poisonous pale } \\
\text { greenish-yellow gas }\end{array}$ \\
\hline
\end{tabular}


Table 12: Nouns whose key noun is case

\begin{tabular}{|c|c|c|c|}
\hline HW & B1 & $\mathrm{KN}$ & DF \\
\hline attache case & $\mathrm{J}$ & case & $\begin{array}{l}\text { a thin hard case with a handle, for car- } \\
\text { rying papers }\end{array}$ \\
\hline test case & $\mathrm{T}$ & case & $\begin{array}{l}\text { a case in a court of law which establishes } \\
\text { a particular principle and is then as a } \\
\text { standard against which other cases can } \\
\text { be judged }\end{array}$ \\
\hline
\end{tabular}

Table 13: Nouns related the noun cloth

\begin{tabular}{|c|c|c|c|}
\hline HW & $\mathrm{B} 1$ & $\mathrm{FF}$ & DF \\
\hline canv & $\mathrm{J}$ & & $\begin{array}{l}\text { strong rough cloth used for tent, sails, bags, } \\
\text { etc. }\end{array}$ \\
\hline$n$ & $s$ & & a strong cotton cloth used esp. for jeans \\
\hline serg & $\mathrm{J}$ & type & $\begin{array}{l}\text { a type of strong cloth, usu. woven from wool, } \\
\text { and used esp. for suits, coats, and dresses }\end{array}$ \\
\hline twee & $\mathrm{S}$ & type & $\begin{array}{l}\text { a type of coarse woolen cloth woven form } \\
\text { threads of several different colours }\end{array}$ \\
\hline
\end{tabular}

16 nouns are 'movable (J)', and 14 nouns are 'absTract.'

Difficulity of semantic marking is also found. For example, lexicographers could not mark 'movable (J)' and 'Solid' systematically. For example, some nouns whose key noun is cloth are marked as 'Solid', and others are marked as 'movable ( $\mathrm{J}$ )' (table 13). This is a problem in gathering of semantic information itself.

\section{Conclusion}

The extraction of semantic relations between verbs and nouns from LDOCE is discussed. Data from the magnetic version of LDOCE is first loaded into a relational database system for simplicity of retrieving. For the extraction of semantic relations, programs to find key verb, key nosn, and function noun have been developed. Using these programs, the thesaurus is automatically produced.

To evaluate the quality of the noun part of the produced thesaurus, it is compared with the semantic markers in LDOCE. Although the produced thesaurus has several problems such as the difficulty of expressing disjunctive concepts, the comparison between the produced thesaurus and semantic markers in LDOCE shows the possibility of sub-classification of 'abstract' nouns.

\section{Acknowledgements}

The authors grateful to Prof. Jun-ichi Tsuji for his fruitful comments on this work. We also wish to thank Mr. Motohiro Fujigaki, Mr. Nobuhiro Kato, and Mr. Keiichi Sakai who inspected LDOCE data carefully.

\section{References}

[Alshwai 1987] Alshaw1, H., Processing Dictionary Definitions with Phrasal Pattern Hierarchies, Computational Linguistics, Vol. 13 (1987).
[Amsler 1987] AMsLen, R. A., How Do I Turn This Book On?, Proc. of Third Annual Conf. of the UW Centre for the NOED, pp. 75-88 (1987).

[Boguraev 1987] Boguraev, B., Experiences with a MachineReadable Dictionary, Proc. of Third Annwal Conf. of the UW Centre for the NOED, pp. 37-50 (1987).

[Nagao 1980] Nagao, M., Tsujil, J., Ueda, Y., TakiYama, M., An Attempt to Computerized Dictionary Data Bases, Proc. of COLING80, pp. 534-542 (1980).

[Nakamura 1986] Nakamura, J., Fujigaki, M., Nagao, M., Longman Dictionary Database and Extraction of its Information, Report on Cognitive Approaches for Discourse Modeling, Kyoto University (1986) (in Japanese).

[Nakamura 1987] Nakamura, J., Sakal, K., Nagao, M., Automatic Analysis of Semantical Relation between English Nouns by an Ordinary English Dictionary, Institute of Electronics, Information and Communication Engineers of Japan, WGNLC, 86-23 (1987) (in Japanese).

[Noël 1982] Michiels, A., NoËL, J., Approaches to Thesaurus Production, Proc. of COLING82, pp. 227-232 (1982).

[Procter 1987] Procter, P., Longman Dictionary of Contemporary English Longman Group Limited, Harlow and London, England (1978).

[Schank 1975]. Schank, R. C., Conceptual Information Processing, New York, North Holland (1975). 